\title{
INFLUENCE OF APICAL PATENCY ON ROOT CANAL TREATMENT OUTCOME: A CONTEMPORARY OVERVIEW
}

\author{
Rahaf Almohareb, Reem Barakat, Aljohara Alshedokhi \\ Department of Clinical Dental Sciences, College of Dentistry, Princess Nourah bint Abdulrahman University, Riyadh, Saudi Arabia
}

\begin{abstract}
Determining the apical limit of root canal preparation has proved to be a matter of continuous debate. During root canal instrumentation, soft tissue or debris get impacted in the apical region causing canal blockage. This can be avoided if apical patency is maintained. A major concern over apical patency is extrusion causing periapical tissue irritation and delaying or hindering periapical healing. The aim of this review was to evaluate the literature regarding the influence of apical patency on success of root canal treatment. A search of the literature was conducted via PubMed using the terms "apical patency" OR "patency file". Inclusion criteria were: articles published in English, between the years 2000 and 2020, and were neither case reports nor reviews. A total of 32 articles were selected. Clinical studies directly investigating the influence of apical patency on root canal treatment outcome are limited. In-vitro and in-vivo studies were found evaluating amount of extrusion, canal cleanliness, and shaping associated with apical patency examined this influence indirectly. According to the available literature, there is little evidence to contraindicate the use of apical patency or suggest it has a negative effect on root canal treatment outcome. However, more evidence of high quality is required to confirm this.
\end{abstract}

KEY WORDS: apical patency, patency, file patency.

J Stoma 2021; 74, 1: 50-56

DOI: https://doi.org/10.5114/jos.2021.104699

\section{INTRODUCTION}

Success of root canal treatment (RCT) depends on neutralizing infection in the entire root canal system through effective root canal preparation [1]. Determining the apical limit of this preparation has proved to be a matter of continuous debate, from which emerged different approaches to managing the apical segment of the root canal [2]. Apical patency as defined by the American Association of Endodontists is a technique intended to maintain the apical part of the root canal free of debris by repeatedly passing a patency file through the apical foramen [3]. Buchanan [4], who was the first to advocate this technique, described the patency file as "a small flexible K-file which passively moves
0.5-1 $\mathrm{mm}$ beyond the apical constriction, without widening it". He went on to describe the patency technique, specifying that the gauge of the patency file should be smaller in diameter than the apical constriction (the narrowest part of the root canal coronal to the foramen) and recommended using an ISO standardized $0.06,0.08$, or 0.10 instrument [4].

The apical plug technique, on the other hand, limits instrumentation within working length of the root canal without using any patency file, and advocates the creation of a dentinal plug at the apical constriction to serve as a biological barrier [2], preventing the extrusion of remnants, irrigating solution, sealers and thermoplastic gutta-percha [5]. Supporters of this technique assume that the apical constriction is the point at

JOURNAL OF STOMATOLOGY CZASOPISMO STOMATOLOGICZNE

ADDRESS FOR CORRESPONDENCE: Reem Barakat, Department of Clinical Dental Sciences, College of Dentistry, Princess Nourah bint Abdulrahman University, Riyadh, Saudi Arabia, e-mail: rmbarakat@pnu.edu.sa

ReCEIVED: 24.10.2020 • ACCEPTED: 07.01.2021 • Published: 30.03.2021 
which the periodontium starts and any instrumentation beyond that is an over-extension that violates the biological integrity and healing of the periapical tissue [2]. Many authors have advocated conserving the soft tissue situated in what is considered the cemental part of the canal (between the apical constriction and major foramen) to promote deposition of newly-formed cementum and improve healing $[6,7]$. Histologically, Ricucci and Langeland [8] showed that instrumentation limited to the apical constriction or $1 \mathrm{~mm}$ short reduced regional tissue damage, and claimed it would be more favorable to healing.

Adequate cleaning and shaping of the apical area of the root canal system has proved particularly challenging $[9,10]$. During root canal instrumentation, pulpal tissue or dentin debris get impacted in the apical region causing canal blockage; a common complication which leads to inadequate root canal preparation due to files losing access to the full working length [11]. This scenario can be avoided if apical patency is maintained during canal instrumentation by introducing the patency file in an alternating manner between shaping files and irrigation steps.

\section{OBJECTIVES}

For long-term favorable prognosis, choices during the process of RCT should be guided by evidence-based decision-making. Thus, the aim of this review was to evaluate what has been discussed in the literature regarding apical patency in RCT and its influence on treatment outcome.

\section{MATERIAL AND METHODS}

A search of the literature was conducted via PubMed using the terms (apical patency) OR (patency file). The process of identifying and selecting the studies can be seen in (Figure 1). Articles published before the year 2000 and/or not in English were excluded, as well as case reports and reviews, with the exception of systematic reviews. Any difference in opinion regarding study inclusion was resolved between the reviewers (R.A. and R.B.) through discussion.

\section{RESULTS}

Of the 183 articles yielded by the search, 32 studies satisfied the inclusion criteria. Data from these studies involving the aim and main findings were obtained (Table 1).

\section{APICAL PATENCY AND PAIN}

Out of the included 32 studies, 8 discussed the association of apical patency with postoperative pain. Two randomized controlled trials each conducted on at least 300 patients with necrotic teeth and apical periodontitis, found that maintaining apical patency was associated with less postoperative pain compared to leaving the canals non-patent. Although no patients suffered from severe pain during the follow-up period, those in the non-patency group experienced more postoperative pain than patients in the patency group during the first 5 postoperative days $[12,13]$.
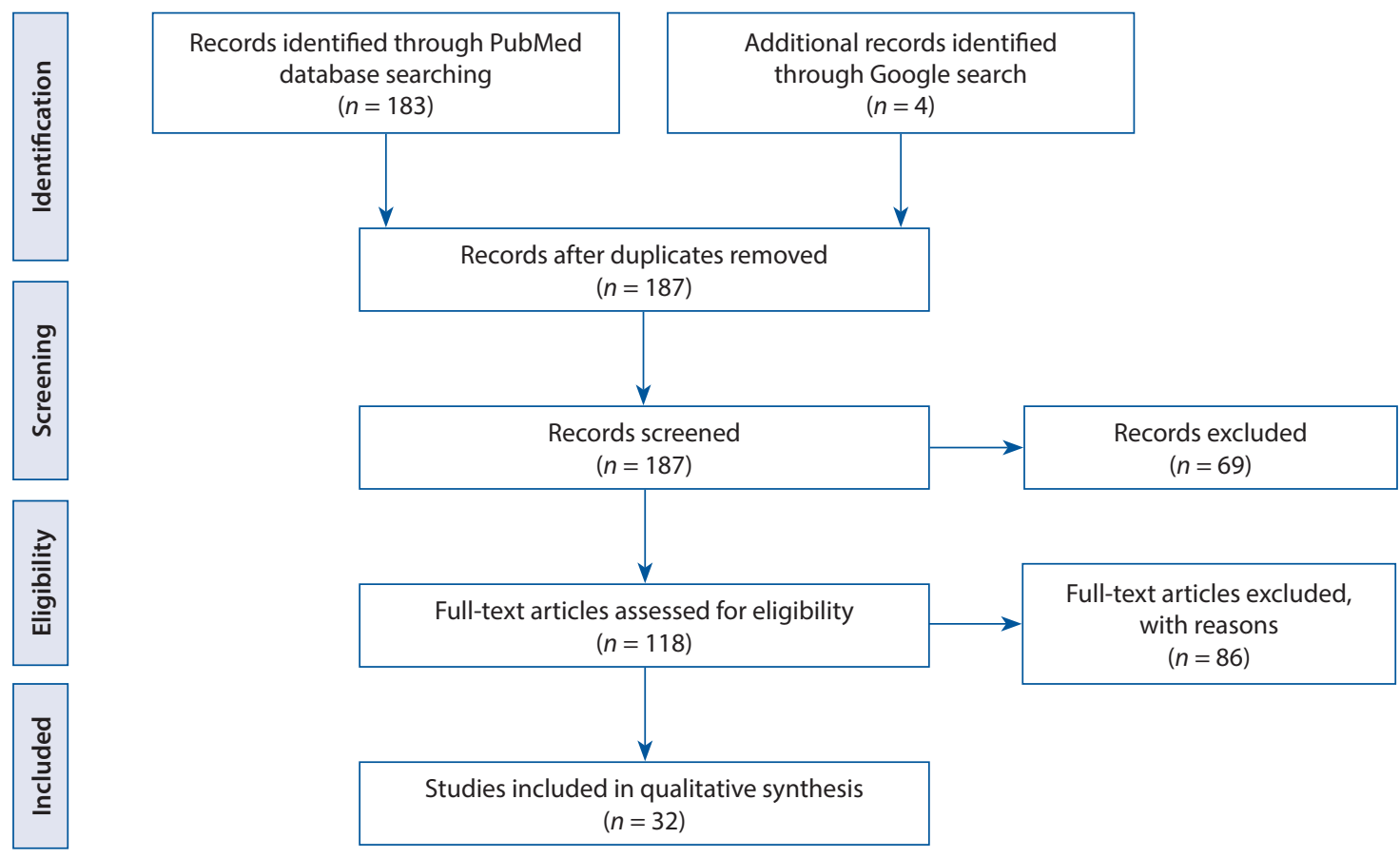

FIGURE 1. PRISMA flowchart on study selection and inclusion 
TABLE 1. A summary of the included studies

\begin{tabular}{|c|c|c|c|c|c|c|}
\hline No. & Study & Year & Study design & Sample size & Topic of influence & Findings \\
\hline 1. & Camões et al. [5] & 2009 & In-vitro & 17 teeth & $\begin{array}{l}\text { Extrusion of } \mathrm{NaOCl} \text { with } \\
\text { and without patency }\end{array}$ & $\begin{array}{l}\text { Irrespective of maintaining irrigant extrusion occurred } \\
\text { with and without maintaining apical patency }\end{array}$ \\
\hline 2. & Holland et al. [7] & 2005 & Animal study & 40 dog teeth & $\begin{array}{l}\text { Periapical healing } \\
\text { and apical patency }\end{array}$ & $\begin{array}{l}\text { Within the proposed experimental conditions, } \\
\text { no apical patency had statistically better results } \\
\text { than those with patency }\end{array}$ \\
\hline 3. & Ng et al. [9] & 2011 & $\begin{array}{l}\text { Randomized } \\
\text { clinical trials }\end{array}$ & 1093 patients & $\begin{array}{l}\text { Periapical healing after } \\
\text { root canal treatment }\end{array}$ & $\begin{array}{l}\text { Achievement of apical patency was found to be } \\
\text { one of the factors that improve periapical healing }\end{array}$ \\
\hline 4. & Ng et al. [10] & 2011 & $\begin{array}{l}\text { Randomized } \\
\text { clinical trials }\end{array}$ & 1093 patients & $\begin{array}{l}\text { Tooth survival after } \\
\text { root canal treatment }\end{array}$ & $\begin{array}{l}\text { Achievement of apical patency was found to be } \\
\text { one of the factors that reduced tooth loss }\end{array}$ \\
\hline 5. & Arora et al. [11] & 2016 & $\begin{array}{l}\text { Randomized } \\
\text { clinical trials }\end{array}$ & $\begin{array}{l}68 \text { necrotic } \\
\text { teeth } \\
\text { with apical } \\
\text { periodontitis }\end{array}$ & Postoperative pain & $\begin{array}{l}\text { Apical patency had no significant influence } \\
\text { on postoperative pain }\end{array}$ \\
\hline 6. & Arias et al. [12] & 2009 & $\begin{array}{l}\text { Randomized } \\
\text { clinical trials }\end{array}$ & $\begin{array}{l}300 \text { necrotic } \\
\text { teeth } \\
\text { with apical } \\
\text { periodontitis }\end{array}$ & Postoperative pain & $\begin{array}{l}\text { Apical patency was associated with significantly } \\
\text { less postoperative pain }\end{array}$ \\
\hline 7. & Yaylali et al. [13] & 2018 & $\begin{array}{l}\text { Randomized } \\
\text { clinical trials }\end{array}$ & $\begin{array}{l}320 \text { necrotic } \\
\text { teeth } \\
\text { with apical } \\
\text { periodontitis }\end{array}$ & Postoperative pain & $\begin{array}{l}\text { Apical patency was associated with significantly } \\
\text { less postoperative pain }\end{array}$ \\
\hline 8. & Arslan et al. [14] & 2019 & $\begin{array}{l}\text { Randomized } \\
\text { clinical trials }\end{array}$ & $\begin{array}{l}50 \text { necrotic } \\
\text { teeth } \\
\text { with apical } \\
\text { periodontitis }\end{array}$ & $\begin{array}{l}\text { Postoperative pain } \\
\text { Periapical healing }\end{array}$ & $\begin{array}{l}\text { Apical patency did not increase the incidence } \\
\text { of postoperative pain or flare-up rate in teeth } \\
\text { with vital/nonvital pulp } \\
\text { Apical patency did not affect endodontic } \\
\text { treatment outcomes }\end{array}$ \\
\hline 9. & Garg et al. [15] & 2017 & $\begin{array}{l}\text { Randomized } \\
\text { clinical trials }\end{array}$ & 80 teeth & Postoperative pain & $\begin{array}{l}\text { Apical patency did not increase the incidence } \\
\text { of postoperative pain }\end{array}$ \\
\hline 10. & $\begin{array}{l}\text { Sharaan and Aboul- } \\
\text { Enein [16] }\end{array}$ & 2012 & $\begin{array}{l}\text { Randomized } \\
\text { clinical trials }\end{array}$ & 80 teeth & Postoperative pain & $\begin{array}{l}\text { Apical patency did not increase the incidence } \\
\text { of postoperative pain }\end{array}$ \\
\hline 11. & Abdulrab et al. [17] & 2018 & Meta-analysis & 4 Studies & Postoperative pain & $\begin{array}{l}\text { Apical patency did not increase the incidence } \\
\text { of postoperative pain }\end{array}$ \\
\hline 12. & Yaylali et al. [18] & 2018 & $\begin{array}{l}\text { Systematic } \\
\text { review }\end{array}$ & $\begin{array}{l}5 \text { randomized } \\
\text { clinical trials } \\
\text { Total of } 848 \\
\text { patients }\end{array}$ & Postoperative pain & $\begin{array}{l}\text { Low to moderate evidence indicate that apical } \\
\text { patency does not increase the incidence } \\
\text { of postoperative pain or flare-up rate in teeth } \\
\text { with vital/nonvital pulp }\end{array}$ \\
\hline 13. & Lopreite et al. [20] & 2014 & In-vitro & $\begin{array}{l}40 \text { extracted } \\
\text { teeth (single } \\
\text { canals) }\end{array}$ & Canal transportation & $\begin{array}{l}\text { There was no significant difference between } \\
\text { using manual or rotary instruments } \\
\text { to achieve apical patency } \\
\text { Both produced some apical foramen deformation }\end{array}$ \\
\hline 14. & $\begin{array}{l}\text { Goldberg and } \\
\text { Massone [21] }\end{array}$ & 2002 & In-vitro & $\begin{array}{l}30 \text { human } \\
\text { maxillary } \\
\text { lateral incisors }\end{array}$ & Canal transportation & $\begin{array}{l}\text { Apical patency did not increase canal transportation } \\
\text { in the apical } 4 \mathrm{~mm}\end{array}$ \\
\hline 15. & $\begin{array}{l}\text { Gonzalez Sanchez et } \\
\text { al. [22] }\end{array}$ & 2010 & In-vitro & $\begin{array}{l}102 \text { human } \\
\text { molars }\end{array}$ & Canal transportation & $\begin{array}{l}\text { No transportation was found when size } 10 \text { stainless } \\
\text { steel reamers were used for apical patency }\end{array}$ \\
\hline 16. & Tsesis et al. [23] & 2008 & Ex-vivo & $\begin{array}{l}40 \text { extracted } \\
\text { molars }\end{array}$ & $\begin{array}{l}\text { Canal transportation } \\
\text { Working length }\end{array}$ & $\begin{array}{l}\text { Apical patency did not increase canal transportation } \\
\text { in the apical } 4 \mathrm{~mm} \\
\text { Apical patency was not associated with loss } \\
\text { of working length }\end{array}$ \\
\hline 17. & $\begin{array}{l}\text { Hasheminia et al. } \\
\text { [24] }\end{array}$ & 2013 & Ex-vivo & $\begin{array}{l}70 \text { mandibular } \\
\text { first molars }\end{array}$ & Canal transportation & $\begin{array}{l}\text { Patency files significantly decreased both apical } \\
\text { transportation and canal straightening }\end{array}$ \\
\hline
\end{tabular}


TABLE 1. Cont.

\begin{tabular}{|c|c|c|c|c|c|c|}
\hline No. & Study & Year & Study design & Sample size & Topic of influence & Findings \\
\hline 18. & $\begin{array}{l}\text { Hasheminia and } \\
\text { Ardestani [25] }\end{array}$ & 2004 & In-vitro & $\begin{array}{l}70 \text { mandibular } \\
\text { first molars }\end{array}$ & Canal transportation & $\begin{array}{l}\text { Patency file in conjunction with passive step back } \\
\text { techniques significantly reduced apical transportation }\end{array}$ \\
\hline 19. & $\begin{array}{l}\text { Trierveiler Paiva } \\
\text { et al. [26] }\end{array}$ & 2018 & In-vitro & 40 teeth & $\begin{array}{l}\text { Regaining apical patency } \\
\text { using reciprocating files } \\
\text { during retreatment }\end{array}$ & $\begin{array}{l}\text { Reciprocating rotary files were more successful } \\
\text { in regaining apical patency in single rooted canals }\end{array}$ \\
\hline 20. & Negishi et al. [27] & 2005 & In-vivo & 57 patients & $\begin{array}{c}\text { Endodontic failure } \\
\text { and inaccessible apical } \\
\text { constriction }\end{array}$ & $\begin{array}{l}\text { Inaccessibility to the apical constriction increases } \\
\text { the risk of root canal treatment failure particularly } \\
\text { in teeth with preoperative periradicular lesion }\end{array}$ \\
\hline 21. & $\begin{array}{l}\text { Abdelsalam } \\
\text { and Hashem [28] }\end{array}$ & 2020 & In-vitro & $\begin{array}{l}43 \\
\text { mandibular } \\
\text { molars }\end{array}$ & Working length & $\begin{array}{l}\text { Apical patency is essential for proper working length } \\
\text { determination with apex locators }\end{array}$ \\
\hline 22. & $\begin{array}{l}\text { Lambrianidis et al. } \\
\text { [29] }\end{array}$ & 2006 & In-vitro & $\begin{array}{l}64 \text { single- } \\
\text { rooted teeth }\end{array}$ & $\begin{array}{l}\text { Canal apical third } \\
\text { removal of intra canal } \\
\text { medicaments }\end{array}$ & $\begin{array}{l}\text { Apical patency facilitated removal of calcium } \\
\text { hydroxide/chlorhexidine medicaments } \\
\text { in the apical third }\end{array}$ \\
\hline 23. & Vera et al. [30] & 2011 & In-vivo & 40 teeth & $\begin{array}{l}\text { Irrigant penetration } \\
\text { in the apical third using } \\
\text { patency and passive } \\
\text { ultrasonic irrigation }\end{array}$ & $\begin{array}{l}\text { Maintaining apical patency and then using passive } \\
\text { ultrasonic activation improves the delivery of irrigants } \\
\text { into the apical third of root canals }\end{array}$ \\
\hline 24. & Vera et al. [31] & 2012 & In-vivo & 43 teeth & $\begin{array}{l}\text { Apical patency and } \\
\text { presence of irrigating } \\
\text { solution in the apical } \\
2 \mathrm{~mm} \text { of large root canals }\end{array}$ & $\begin{array}{l}\text { Significantly more canals had irrigant in the apical } \\
2 \mathrm{~mm} \text { when apical patency was maintained }\end{array}$ \\
\hline 25. & Vera et al. [32] & 2012 & In-vivo & 71 teeth & $\begin{array}{l}\text { Apical patency and gas } \\
\text { bubbles during irrigation }\end{array}$ & $\begin{array}{l}\text { Apical patency significantly leads to minimizing } \\
\text { the presence of gas bubbles in the middle } \\
\text { and cervical thirds during root canal preparation }\end{array}$ \\
\hline 26. & $\begin{array}{l}\text { Lambrianidis et } \\
\text { al. [35] }\end{array}$ & 2001 & In-vitro & $\begin{array}{l}33 \text { maxillary } \\
\text { incisors }\end{array}$ & Periapical extrusion & $\begin{array}{l}\text { Without maintaining apical patency, greater } \\
\text { extrusion occurred when the apical constriction } \\
\text { remained intact compared to after its enlargement }\end{array}$ \\
\hline 27. & Kini et al. [37] & 2015 & In-vitro & 50 teeth & $\begin{array}{l}\text { Inoculation of periapical } \\
\text { tissue with contaminated } \\
\text { patency file }\end{array}$ & $\begin{array}{l}\mathrm{NaOCl} \text { in the canals prevented the inoculation } \\
\text { of periapical tissue with bacteria contaminated } \\
\text { patency files } \\
\text { NAOCL was sufficient to kill microorganisms } \\
\text { on the file }\end{array}$ \\
\hline 28. & Izu et al. [38] & 2004 & In-vitro & 28 teeth & $\begin{array}{l}\text { Inoculation of periapical } \\
\text { tissue with contaminated } \\
\text { patency file }\end{array}$ & $\begin{array}{l}\mathrm{NaOCl} \text { in the canals prevented the inoculation } \\
\text { of periapical tissue with bacteria contaminated } \\
\text { patency files } \\
\text { NAOCL was sufficient to kill microorganisms on } \\
\text { the file }\end{array}$ \\
\hline 29. & Deonizio et al. [41] & 2013 & In-vitro & $\begin{array}{l}40 \text { mandibular } \\
\text { incisors }\end{array}$ & $\begin{array}{l}\text { Amount of debris } \\
\text { extrusion during } \\
\text { retreatment }\end{array}$ & $\begin{array}{l}\text { Apical patency did not influence the amount } \\
\text { of extruded filling material during retreatment } \\
\text { with Protaper Universal System }\end{array}$ \\
\hline 30. & Tinaz et al. [42] & 2005 & In-vitro & 52 teeth & $\begin{array}{l}\text { Periapical extrusion } \\
\text { while manual vs. rotary } \\
\text { instrumentation }\end{array}$ & $\begin{array}{l}\text { Apical extrusion exists with apical patency technique } \\
\text { whether canals are instrumented using K-files } \\
\text { or rotary instrumentation with ProFile .04 taper } \\
\text { It increased however, as the diameter of the apical } \\
\text { patency increases }\end{array}$ \\
\hline 31. & De-Deus et al. [43] & 2019 & In-vitro & 10 teeth & $\begin{array}{l}\text { Regaining apical patency } \\
\text { using reciprocating files } \\
\text { during retreatment }\end{array}$ & $\begin{array}{l}\text { No significant difference was found between } \\
\text { M-Wire Reciproc and Reciproc Blue files } \\
\text { in removing filling materials } \\
\text { Both files reestablished apical patency } \\
\text { in all specimens }\end{array}$ \\
\hline 32. & Carpenter et al. [44] & 2014 & In-vitro & 86 teeth & $\begin{array}{l}\text { Regaining apical patency } \\
\text { during retreatment } \\
\text { of MTA containing sealer } \\
\text { and gutta percha }\end{array}$ & $\begin{array}{l}\text { Gutta percha solvents allowed regaining apical } \\
\text { patency when retreating canals filled with MTA } \\
\text { containing sealer and gutta percha }\end{array}$ \\
\hline
\end{tabular}


The majority of the studies, however, found no significant difference, as far as postoperative pain was concerned, concluding that apical patency was not associated with an increase in the incidence of postoperative pain [11, 14-18]. One randomized controlled clinical trial [11] conducted on necrotic mandibular molars with apical periodontitis found that while postoperative pain scores and number of analgesic doses taken to achieve pain relief were less in the patency group, it was not statistically significant. Maintaining apical patency did not increase postoperative pain whether a single-visit or two-visit RCT procedure was used. However, apical patency significantly reduced pain scores that were observed 24 hours postoperatively [11]. These findings could not be generalized to cases of vital teeth without apical periodontitis, as the trial was limited to necrotic teeth with apical periodontitis. In 2018, a meta-analysis and systematic review of randomized clinical trials exploring the influence of apical patency on pain associated with RCT $[17,18]$ concluded that the evidence - although of low to moderate quality - suggested that apical patency does not increase the incidence of postoperative pain associated with RCT or flare-up rate in cases of both vital or necrotic teeth.

\section{APICAL PATENCY AND FORAMEN TRANSPORTATION}

Transportation of the apical foramen during root canal instrumentation may result in incomplete removal of debris and jeopardize the outcome of the RCT [19]. Lopreite et al.[20] conducted an in-vitro study in 2014 on sound teeth recently extracted for orthodontic reasons, to evaluate preservation of the original shape of the apical foramen when patency is performed using either manual or nickel-titanium rotary instrumentation. The roots were examined at $\times 100$ magnification, photographed, and mapped using image managing software. Using both rotary and manual instrumentation to establish apical patency in single straight canals showed foramen deformation in some, but not the majority of cases [20].

In regards to transportation in the apical $4 \mathrm{~mm}$ of curved canals, other in-vitro studies concluded that apical patency was not associated with transportation [21-23] specifically, when a size 08 stainless steel K-Flex file or a size 10 reamer were used. Furthermore, a couple of studies even reported that apical patency reduced the degree of apical transportation and curve straightening $[24,25]$.

\section{APICAL PATENCY AND ACCURACY OF WORKING LENGTH}

It has been reported that a short root canal preparation increases the risk of RCT failure by 5.3 folds, especially in teeth having a periapical lesion $[26,27]$. Tsesis et al. [23] found that maintaining apical patency did not influence loss of working length in curved canals.
Recently, however, a study in 2020, examining the influence of apical patency on the accuracy of two different kinds of apex locators concluded that it is essential for reliable working length determination using apex locators to maintain a patent apex [28].

\section{APICAL PATENCY AND CANAL CLEANLINESS}

The primary purpose of apical patency is to ensure that the patent canal is clean apically [22]. As a result of the anatomical complexity of the root canal system, it is not possible to clean the whole surface of the root canal using shaping files alone, which establishes the indispensable role of irrigation in root canal preparation. Using radiopaque solution, an in-vivo study determined whether the use of patency was associated with more irrigating solution in the canal apical third after using passive ultrasonic activation [29]. Canals were irrigated with a radiopaque contrast and apical patency was achieved using a size $10 \mathrm{~K}$-file, extended $1 \mathrm{~mm}$ beyond the working length. The digital images revealed there were significantly more patent canals with irrigant in the apical third compared to the non-patent canals. The study concluded that apical patency combined with passive ultrasonic activation enhances the transmission of irrigants into the apical third of root canals [30]. A similar study arrived at the same conclusion in regards to irrigant delivery to the apical area of large root canals [31]. Vera et al. [32] also examined the effect of apical patency on the gas bubbles located within the canal coronal and middle thirds which restrict irrigant flow during canal preparation. Irrigation using sodium hypochlorite $(\mathrm{NaOCl})$ with a contrast medium revealed that maintaining apical patency significantly minimized the gas bubbles in large canals.

The incomplete removal of intracanal medicaments, such as calcium hydroxide, can adversely affect the properties of some root canal filling materials thus influencing RCT outcome [33]. In-vitro studies reported a statistically significant association between the efficient removal of calcium hydroxide or chlorohexidine and the combined use of patency file and irrigation [29].

\section{APICAL PATENCY AND BIOLOGICAL CONSIDERATIONS}

Apical patency creates an open passage to the apical foramen, clear from infection-containing debris (dentin chips or pulpal tissue). There are those who view this with concern due to the possibility of bacterial extrusion $[34,35]$, and its subsequent influence on treatment outcome in the light of studies - although rare - that have reported root canal failure due to bacteria found in the periapical area [36]. Two in-vitro studies explored this possibility and reported that when using a patency file in canals filled with $\mathrm{NaOCl}$, this prevented the inoculation of periapical tissue with bacteria $[37,38]$. How- 
ever, in these studies, the files were contaminated with only Streptococcus sanguis which does not reflect the diverse bacterial population found in root canals undergoing endodontic treatment, and which may include more resistant bacterial strains [36].

\section{APICAL PATENCY AND EXTRUSION}

Extrusion of debris and irrigant solutions beyond the foramen is associated with periapical inflammation and delayed healing of apical periodontitis $[39,40]$. One in-vitro study examining apical extrusion found no statistical difference in the amount of extrusion beyond both intact and small-sized apical foramina whether patency files of different sizes were used or not [5]. Deonizio et al. [41] arrived at a similar conclusion, showing that apical patency does not impact the amount of extruded filling material during root canal retreatment. Paradoxically, Lambrianidis et al. [35] reported that more extrusion occurred with an intact apical constriction compared to when it was enlarged. They related these finding to the probable creation of an apical plug due to not performing apical patency in their study. While Tinaz et al. [42] showed that apical extrusion of material increased using larger diameter patency files.

\section{APICAL PATENCY AND OVERALL TREATMENT SUCCESS}

Two randomized controlled clinical studies exploring factors associated with tooth survival and periapical healing following RCT $[9,10]$ reported that maintaining apical patency is one of the important factors positively impacting periapical healing and tooth survival after RCT. Negishi et al. [27] reported an increase in failure risk with an inaccessible apical constriction especially in teeth with periapical lesions. On the other hand, a recently published randomized clinical trial evaluating the effect of maintaining apical patency on healing of periapical lesions associated with necrotic teeth, demonstrated that success was similar in both patency and non-patency groups [14].

Only an animal model study examining periapical healing after RCT with or without apical patency in dogs [7], found significant healing in the non-patency group. It was argued that there was an absence of pathogenic bacteria in that study, which explained the decreased outcome being associated with patency, due to mechanical irritation of the periapical tissues.

Achieving apical patency was also cited as a criterion of efficacy in root canal retreatment procedures $[26,43,44]$.

\section{CONCLUSIONS}

Clinical studies directly investigating the influence of apical patency on RCT outcome are limited. In-vitro and in-vivo studies evaluating amount of extrusion, canal cleanliness, and shaping examined this influence indirectly. According to the available literature, there is little evidence to contraindicate the use of apical patency or suggest it has a negative effect on RCT outcome. However, more evidence of high quality is required to confirm this.

\section{ACKNOWLEDGMENT}

This research was funded by the Deanship of Scientific Research at Princess Nourah bint Abdulrahman University through the Fast-track Research Funding Program.

\section{CONFLICT OF INTEREST}

The authors declare no potential conflicts of interest with respect to the research, authorship, and/or publication of this article.

\section{References}

1. Bergenholtz G. Assessment of treatment failure in endodontic therapy. J Oral Rehabil 2016; 43: 753-758.

2. Simon S, Machtou P, Adams N, Tomson P, Lumley P. Apical limit and working length in endodontics. Dent Update 2009; 36: 146-153.

3. American Association of Endodontists. Glossary of endodontic terms 2016. Gloss Endod Terms 2015; 9: 43.

4. Buchanan LS. Management of the curved root canal. J Calif Dent Assoc 1989; 17: 18-27.

5. Camões ICG, Salles MR, Fernando MVM, Freitas LF, Gomes CC. Relationship between the size of patency file and apical extrusion of sodium hypochlorite. Indian J Dent Res 2009; 20: 426-430.

6. Ricucci D, Lin LM, Spångberg LSW. Wound healing of apical tissues after root canal therapy: a long-term clinical, radiographic, and histopathologic observation study. Oral Surg Oral Med Oral Pathol Oral Radiol Endod 2009; 108: 609-621.

7. Holland R, Sant' Anna A, De Souza V, et al. Influence of apical patency and filling material on healing process of dogs' teeth with vital pulp after root canal therapy. Braz Dent J 2005; 16: 9-16.

8. Ricucci D, Langeland K. Apical limit of root canal instrumentation and obturation, part 1. Literature review. Int Endod J 1998; 31: 384-393.

9. Ng YL, Mann V, Gulabivala K. A prospective study of the factors affecting outcomes of nonsurgical root canal treatment: part 1: periapical health. Int Endod J 2011; 44: 583-609.

10. Ng YL, Mann V, Gulabivala K. A prospective study of the factors affecting outcomes of non-surgical root canal treatment: Part 2: tooth survival. Int Endod J 2011; 44: 610-625.

11. Arora M, Sangwan P, Tewari S, Duhan J. Effect of maintaining apical patency on endodontic pain in posterior teeth with pulp necrosis and apical periodontitis: a randomized controlled trial. Int Endod J 2016; 49: 317-324.

12. Arias A, Azabal M, Hidalgo JJ, de la Macorra JC. Relationship between postendodontic pain, tooth diagnostic factors, and apical patency. J Endod 2009; 35: 189-192.

13. Yaylali IE, Kurnaz S, Tunca YM. Maintaining apical patency does not increase postoperative pain in molars with necrotic pulp and apical periodontitis: a randomized controlled trial. J Endod 2018; 44: 335-340.

14. Arslan H, Yıldız ED, Topçuoğlu HS, Tepecik E, Ayaz N. Success of maintaining apical patency in teeth with periapical lesion: a randomized clinical study. Quintessence Int (Berl) 2019; 50: 686-693. 
15. Garg N, Sharma S, Chhabra A, Dogra A, Bhatia R, Thakur S. Clinical evaluation of maintenance of apical patency in postendodontic pain: an in vivo study. Endodontology 2017; 29: 115-119.

16. Sharaan ME, Aboul-Enein NM. Relationship between post-preparation pain and apical patency: a randomized clinical trial. Gulf Med Journalal J 2012; 1: 96-101.

17. Abdulrab S, Rodrigues JC, Al-maweri SA, Halboub E, Alqutaibi AY, Alhadainy H. Effect of apical patency on postoperative pain: a metaanalysis. J Endod 2018; 44: 1467-1473.

18. Yaylali IE, Demirci GK, Kurnaz S, Celik G, Kaya BU, Tunca YM. Does maintaining apical patency during instrumentation increase postoperative pain or flare-up rate after nonsurgical root canal treatment? A systematic review of randomized controlled trials. J Endod 2018; 44: 1228-1236.

19. López FU, Travessas JAC, Fachin E, Fontanella V, Grecca F. Apical transportation: two assessment methods. Aust Endod J 2009; 35: 85-88.

20. Lopreite G, Basilaki J, Romero M, Hecht P. Evaluation of apical foramen deformation produced by manual and mechanized patency maneuvers. Acta Odontol Latinoam 2014; 27: 77-81.

21. Goldberg F, Massone EJ. Patency file and apical transportation: an in vitro study. J Endod 2002; 28: 510-511.

22. Gonzalez Sanchez JA, Duran-Sindreu F, Albuquerque Matos M, et al. Apical transportation created using three different patency instruments. Int Endod J 2010; 43: 560-564.

23. Tsesis I, Amdor B, Tamse A, Kfir A. The effect of maintaining apical patency on canal transportation. Int Endod J 2008; 41: 431-435.

24. Hasheminia SM, Farhadi N, Shokraneh A. Effect of patency file on transportation and curve straightening in canal preparation with ProTaper system. ISRN Dent 2013; 2013: 704027.

25. Hasheminia M, Ardestani M. The effect of using patency file on apical transportation in canals prepared with passive step back technique. J Res Med Sci 2004; 9: 210-215.

26. Trierveiler Paiva RC, Solda C, Vendramini F, Vanni JR, Baldissarelli Marcon F, Fornari VJ. Regaining apical patency with manual and reciprocating instrumentation during retreatment. Iran Endod J 2018; 13: 351-355.

27. Negishi J, Kawanami M, Ogami E. Risk analysis of failure of root canal treatment for teeth with inaccessible apical constriction. J Dent 2005; 33: 399-404.

28. Abdelsalam N, Hashem N. Impact of apical patency on accuracy of electronic apex locators: in vitro study. J Endod 2020; 46: 509-514.

29. Lambrianidis T, Kosti E, Boutsioukis C, Mazinis M. Removal efficacy of various calcium hydroxide/chlorhexidine medicaments from the root canal. Int Endod J 2006; 39: 55-61.

30. Vera J, Arias A, Romero M. Effect of maintaining apical patency on irrigant penetration into the apical third of root canals when using passive ultrasonic irrigation: an in vivo study. J Endod 2011; 37: 1276-1278.

31. Vera J, Hernández EM, Romero M, Arias A, Van Der Sluis LWM Effect of maintaining apical patency on irrigant penetration into the apical two millimeters of large root canals: an in vivo study. J Endod 2012; 38: 1340-1343.

32. Vera J, Arias A, Romero M. Dynamic movement of intracanal gas bubbles during cleaning and shaping procedures: the effect of maintaining apical patency on their presence in the middle and cervical thirds of human root canals - an in vivo study. J Endod 2012; 38: 200-203.

33. Ghabraei S, Bolhari B, Yaghoobnejad F, Meraji N. Effect of intracanal calcium hydroxide remnants on the push-out bond strength of two endodontic sealers. Iran Endod J Spring 2017; 12: 168-172.

34. Torabinejad M, Walton R. Endodontics: Principles and Practice. Chapter 15. $4^{\text {th }}$ ed. Saunders; 2008

35. Lambrianidis T, Tosounidou E, Tzoanopoulou M. The effect of maintaining apical patency on periapical extrusion. J Endod 2001; 27: 696-698.

36. Nair PNR. On the causes of persistent apical periodontitis: a review. Int Endod J 2006; 39: 249-281
37. Kini S, Shetty SV, Shetty KH, Kudva A, Kumar P. The efficiency of $2.5 \%$ sodium hypochlorite in preventing inoculation of periapical tissues with contaminated patency files: an ex vivo evaluation. J Pharm Bioallied Sci 2015; 7: 563-566.

38. Izu KH, Thomas SJ, Zhang P, Izu AE, Michalek S. Effectiveness of sodium hypochlorite in preventing inoculation of periapical tissues with contaminated patency files. J Endod 2004; 30: 92-94.

39. Gernhardt CR, Eppendorf K, Kozlowski A, Brandt M. Toxicity of concentrated sodium hypochlorite used as an endodontic irrigant. Int Endod J 2004; 37: 272-280.

40. Siqueira JF. Microbial causes of endodontic flare-ups. Int Endod J 2003; 36: 453-463.

41. Deonizio MDA, Sydney GB, Batista A, Pontarolo R, Guimarães PRB, Gavini G. Influence of apical patency and cleaning of the apical foramen on periapical extrusion in retreatment. Braz Dent J 2013; 24: 482-486.

42. Tinaz AC, Alacam T, Uzun O, Maden M, Kayaoglu G. The effect of disruption of apical constriction on periapical extrusion. J Endod 2005; 31: 533-535.

43. De-Deus G, Belladonna FG, Zuolo AS, et al. Effectiveness of Reciproc Blue in removing canal filling material and regaining apical patency. Int Endod J 2019; 52: 250-257.

44. Carpenter MT, Sidow SJ, Lindsey KW, Chuang A, McPherson JC. Regaining apical patency after obturation with gutta-percha and a sealer containing mineral trioxide aggregate. J Endod 2014; 40: 588-590. 